\title{
Correlation of vertical dimension with lip position, nasolabial angle and incisal display at rest and at smile in young adults
}

\author{
Dr. Jahamgeer Badusha S', Dr. Purva Joneja², Dr Anshu Agarwal ${ }^{3}$, Dr. Deepak Singh Choudhary ${ }^{4}$ \\ ${ }^{1}$ PG Student, ${ }^{2}$ Professor and HOD, ${ }^{3}$ Professor, ${ }^{4}$ Assistant Professor, \\ Department Of Orthodontics and Dentofacial Orthopedics, \\ Bhabha College of Dental Sciences, Bhopal, (M.P)
}

Corresponding author: Dr. Jahamgeer Badusha S; Email: jahamgeerjbs@gmail.com

\section{ABSTRACT}

Introduction: Photography has been given a great importance in diagnosis in orthodontics, the study of certain aesthic parameter on digitilzed photographs can provide an additional diagnostic tool. This study is designed to compare facial parameters and various photographic parameters among patients with long, average, short faces in central Indian population. Also an alternative method to cephalometric analysis needs to be worked upon which is reliable, easily assessable and convenient for multiple usage by the orthodontist to direct his/her treatment.

Materials and Methods: 150 subjects ( 75 males and 75 females) selected and examined by two methods clinical examination and photographic examination by using ImageJ software.

Results: The results of this study shows there is significant correlation between vertical dimension, incisal display upper lip length, lower lip length and nasolabial angle and there is no significant difference between clinical examination and photographic examination done with Image $\mathrm{J}$ software.

Conclusion: This study concluded that the vertical proportions of facial soft tissue follow the underlying vertical skeletal pattern, high vertical dimension is associated with short upper lip, more incisal display and high clinical FMA. The low vertical dimension is associated with acute nasolabial angle and low clinical FMA. Photogrammetry was found to be a quick easy, cost effective and reliable diagnostic tool which can reduce radiation exposure and reduce the number of cephalograms during treatment.

KEYWORDS: Vertical dimension, Incisal display, Upper lip length, Lower lip length, Nasolabial angle.

\section{INTRODUCTION}

The pleasant dental esthetics has been rated as an important factor for psychosocial well being. Ideal occlusion should certainly remain the primary functional goal of orthodontics but the esthetic outcome is critical for patient satisfaction. Record taking in orthodontics is considered immensely important as it aids in determining the finest possible treatment plan for each case. ${ }^{1}$ This study is designed to compare facial and dental dimensions and various photographic parameters among patients with long, average, short faces in central Indian population. With the rise in demands of radiation safety there is a need to minimize radiation exposure and hence this technique of photographic diagnostic analysis is useful. ${ }^{2}$ An alternative method to cephalometric analysis needs to be worked upon which is reliable, easily assessable and convenient for multiple usage by the orthodontist \& digital photographic analysis could be one of the answer. The application of photogrammetry in orthodontics was first proposed by Stoner, who compared pre- and post-treatment profiles with ideal profiles. Different authors have included soft tissue parameters in photogrammetry, and various facial soft tissue analyses based on standardized photogrammetri. Other photographic methods have also been used to quantify facial aesthetics. Facial soft tissue analysis has been conducted using newer threedimensional (3D) methods, such as laser surface and, more recently, scanning digital 3D photogrammetry. Photogrammetry has been introduced as an alternative to direct measurements to obtain distances between facial landmarks using both two-dimensional and 
three-dimensional methods. Obtaining measurements from photographs is less intrusive to the patient, more cost-effective, provides a permanent record of the face that can be accessed at a later time, and offers consistency in longitudinal studies in which different observers with different direct measuring techniques might participate. ${ }^{3}$ Facial harmony and balance are determined by the facial skeleton and its soft tissue drape. The evaluation of the soft tissue profile is vital in smile designing. Soft tissue changes have been shown to accompany growth, orthodontic treatment as well as plastic surgery. It is for these reasons that the soft tissue profile must be carefully examined before a decision regarding smile enhancement, orthodontic treatment and/or orthognathic surgery can be made. ${ }^{4}$ In depth clinical and photographic analysis among various vertical facial patterns depicting correlations with lip position, nasolabial angle and incisal display in all types of malocclusion in central Indian population is still lacking. The purpose of the present study is to determine whether there should be some relation in certain esthetic parameters, so that an additional all diagnostic parameter could be available to the orthodontist in treatment approach.

\section{OBJECTIVES}

To evaluate the gender specific effect of Vertical Dimension (VD), high VD, average VD and low VD on the position of lip, amount of incisal display and nasolabial angle at smile and at rest.

To emphasize on this technique of photographic diagnostic analysis to give due attention to this essential diagnostic aid.

\section{MATERIAL \& METHOD}

The sample will consist of central Indian population of young patients age ranging from $18-25$ years, equally including both male and female in genders having any VD (high/average/low) irrespective of any malocclusion (Angles class I/class II/class III). The sample included in this study is selected from the patients referred to Bhabha college of dental science (BCDS), Bhopal for orthodontic consultation and treatment purpose

Nikon D3400 digital camera with lens AF-P DX Nikon 18$55 \mathrm{~mm}, 70-300 \mathrm{~mm}$ f/4.5-6.3G ED VR lens will be used for taking photographs. The camera mounted on a tripod stand with the lens and positioned parallel to the true perpendicular of the face in natural head position. A distance of 3 feet was maintained between the camera and the subject. The subject was made to face a mirror placed $120 \mathrm{~cm}$ away to aid in obtaining Natural Head Posture (NHP). A metal scale attached to a drip stand was secured just side of the subject. Four photographs (frontal rest, frontal smile, profile rest and profile smile) from each of 150 subjects were taken at natural head position.The images are transferred to imageJ software. Image $\mathrm{J}$ is a Java-based image processing program developed at the National Institutes of Health and the Laboratory for Optical and Computational Instrumentation (LOCl, University of Wisconsin) ${ }^{1,3}$ Its first version, Image J 1.x, is developed in the public domain, while Image 2 and the related projects SciJava, ImgLib2, and SCIFIO are licensed with a permissive BSD-2 license. The project developer, Wayne Rasband, retired from the Research Services Branch of the National Institute of Health in 2010.

While in clinical examination measurement patients will $b$ asked to sit on a chair in relaxed posture, making their $\mathrm{FH}$ plane parallel to the floor and maintaining the occlusal contact, clinically, measurements will b done using vernier calliper. After clinical examination, 4 extra oral photographs will be taken of the same patient. The frame that best represents the patient's natural unstrained social smile that is the most reproducible smile in all the frames will be selected8. Frontal at rest, frontal at smile, profile at rest and profile at smile of each patient will be taken, keeping the patient camera distance of 3 feet and by placing a metal scale on one side of the patient's head. The image received will be analyzed by using ImageJ software. Parameters includes, Vertical dimension, Incisal display, Upper lip length, Lower lip length, Nasolabial angle, Clinical FMA. Land marks includes, Subnasale, Stomion superioris, Stomion inferioris, Soft tissue menton, F-H plane, Mandibular plane, Columella of nose.

\section{Inclusion Criteria:}

Male and female patients irrespective of any malocclusion (Class I/Class II/Class III)

Patient age ranging from 18-25 years

Patient with all facial patterns

Patient with no history of previous orthodontic treatment Patient with full set of permanent dentition irrespective of presence or absence of third molar

\section{Exclusion Criteria:}

Patient age group other than 18-25 years

Handicapped and mentally compromised patients

Patient not willing to participate in this study - non consent patients

Patient with any history of trauma, congenital defects, systemic disorders

Patient with history of orthognathic surgery or plastic surgery

Patient with cleft lip and palate

Any facial or skeletal asymmetry 
Table 1: Clinical Examination Frontal Measurements

\begin{tabular}{|c|c|c|c|c|c|c|}
\hline \multirow{2}{*}{ SL No. } & \multirow{2}{*}{ PARAMETERS } & \multicolumn{2}{|c|}{ NORMAL RANGE } & \multirow{2}{*}{$\begin{array}{l}\text { MEASURED VALUE } \\
\text { (At rest) }\end{array}$} & \multirow{2}{*}{$\begin{array}{l}\text { MEASURED VALUE } \\
\text { (At smile) }\end{array}$} & \multirow[t]{2}{*}{ INFERENCE } \\
\hline & & Female & Male & & & \\
\hline 1 & Vertical dimension & $55.40+/-3.9$ & $61.0+/-5.4$ & 55 & 54 & Low \\
\hline 2 & Incisal display & $2.23+/-1.2$ & $2.23+/-1.2$ & 0 & 7 & Average \\
\hline 3 & Upper lip length & $16.94+/-2.0$ & $19.0+/-2.5$ & 17 & 15 & Average \\
\hline 5 & Lower lip length & $37.50+/-2.7$ & $41.3+/-3.7$ & 39 & 36 & Average \\
\hline
\end{tabular}

Photographic Examination with Image J Software Profile Measurements At Rest (Fig 7-11)

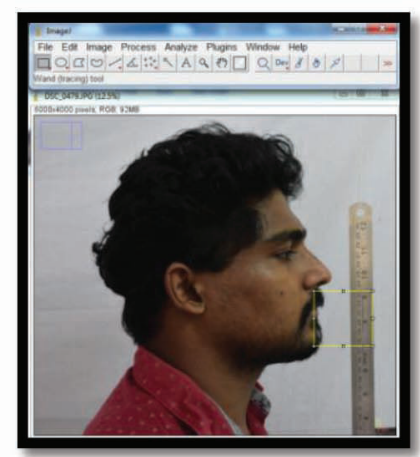

Fig.7 Vertical dimension

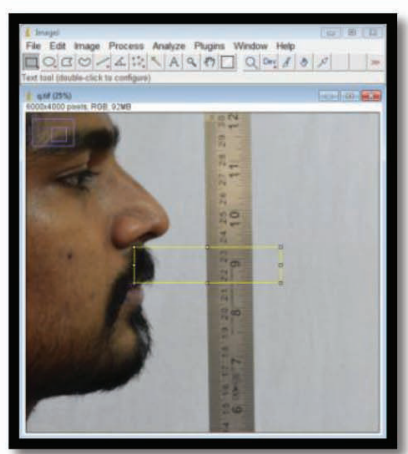

Fig.8 Upper lip length

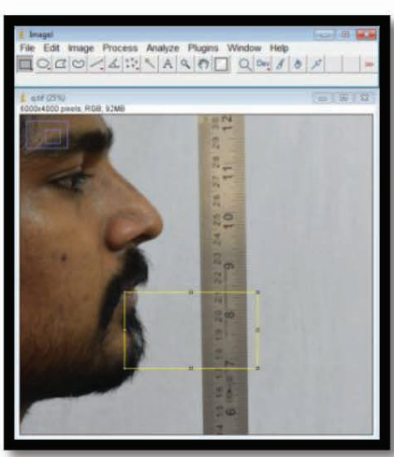

Fig.9 Lower lip length

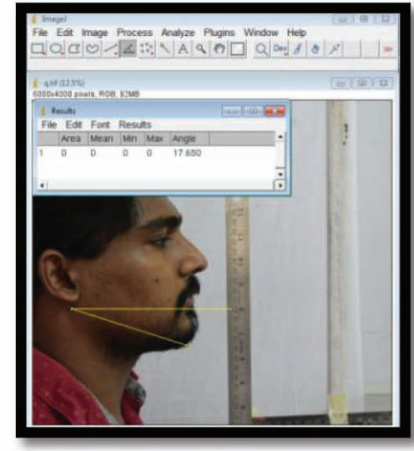

Fig.10 Clinical FMA

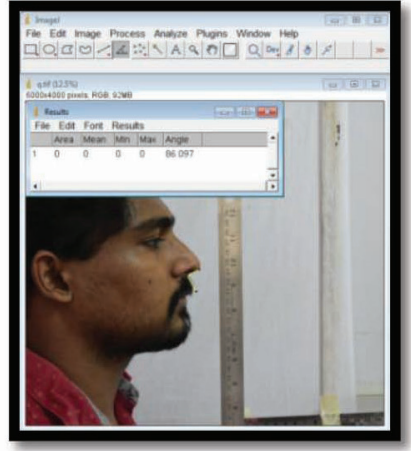

Fig.11 Nasolabial angle

Table.2 Photographic Examination with Image J Software Profile Measurements At Smile (Fig 12-16)

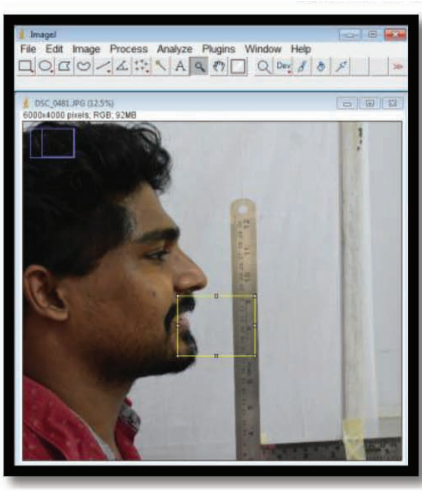

Fig.12 Vertical dimension

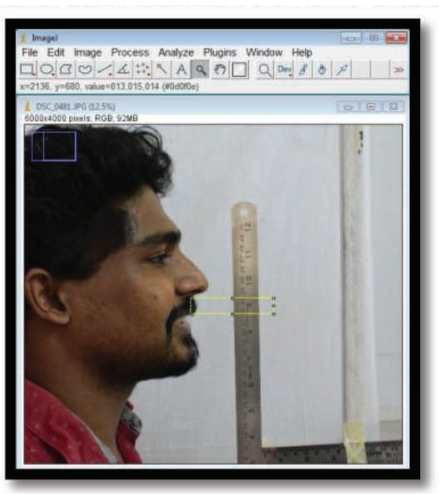

Fig.13 Upper lip length Fig.

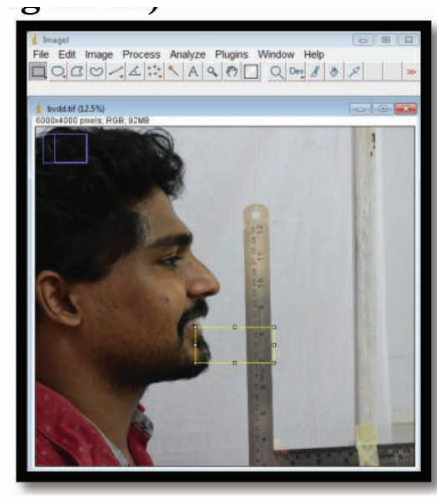

Fig. 14 Lower lip length 


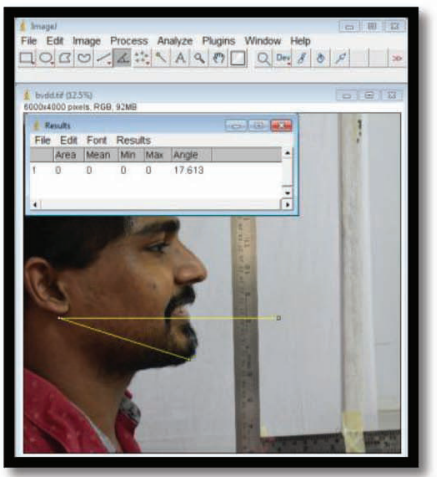

Fig. 15 Clinical FMA

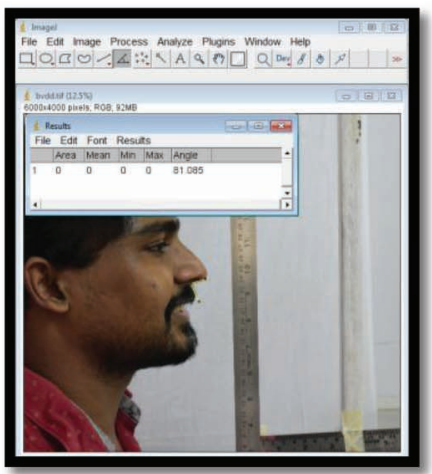

Fig.16 Nasolabial angle

Table 2: Photographic Examination with Image J Software Profile Measurements at Rest and at Smile

\begin{tabular}{|l|l|c|c|c|c|c|}
\hline \multirow{2}{*}{ SL No. } & \multirow{2}{*}{ PARAMETERS } & \multicolumn{2}{|c|}{ NORMAL RANGE } & \multirow{2}{*}{$\begin{array}{c}\text { MEASURED VALUE } \\
\text { (At rest) }\end{array}$} & $\begin{array}{c}\text { MEASURED VALUE } \\
\text { (At smile) }\end{array}$ & INFERENCE \\
\cline { 3 - 4 } & Female & Male & & 54 & Low \\
\hline 1 & Vertical dimension & $55.40+/-3.9$ & $61.0+/-5.4$ & 55 & 7 & Average \\
\hline 2 & Incisal display & $2.23+/-1.2$ & $2.23+/-1.2$ & 0 & 15 & Average \\
\hline 3 & Upper lip length & $16.94+/-2.0$ & $19.0+/-2.5$ & 17 & 36 & Average \\
\hline 4 & Lower lip length & $37.50+/-2.7$ & $41.3+/-3.7$ & 39 & & \\
\hline
\end{tabular}

\section{RESULTS}

Table 3: Correlation of values for the study pattern obtained by frontal clinical examination and digital photographic examination

\begin{tabular}{|c|c|c|c|c|c|c|}
\hline Parameters & group & $\mathbf{N}$ & Mean & Std. Deviation & $\mathrm{T}$ value & P Value \\
\hline \multirow{2}{*}{$\begin{array}{l}\text { vertical } \\
\text { dimension }\end{array}$} & Clinical & 150 & 63.29 & 4.58 & \multirow[t]{2}{*}{0.195} & \multirow[t]{2}{*}{0.84} \\
\hline & Photograph & 150 & 63.12 & 4.54 & & \\
\hline \multirow{2}{*}{$\begin{array}{l}\text { Incisal } \\
\text { display }\end{array}$} & Clinical & 150 & 0.68 & 1.53 & \multirow[t]{2}{*}{0.110} & \multirow[t]{2}{*}{0.91} \\
\hline & Photograph & 150 & 0.72 & 1.55 & & \\
\hline \multirow{2}{*}{$\begin{array}{l}\text { upper lip } \\
\text { length }\end{array}$} & Clinical & 150 & 18.61 & 2.62 & \multirow[t]{2}{*}{0.44} & \multirow[t]{2}{*}{0.65} \\
\hline & Photograph & 150 & 18.38 & 2.64 & & \\
\hline \multirow{2}{*}{$\begin{array}{l}\text { lower lip } \\
\text { length }\end{array}$} & Clinical & 150 & 40.16 & 3.95 & \multirow[t]{2}{*}{0.15} & \multirow[t]{2}{*}{0.88} \\
\hline & Photograph & 150 & 40.04 & 3.89 & & \\
\hline
\end{tabular}

\section{photographic values $\approx$ clinical values}

The measurements included in the frontal result includes vertical dimension, incisal display, Upper lip length and lower lip length.

The mean vertical dimension by using the clinical method was $63.29 \pm 4.58 \mathrm{~mm}$ while using photographic method was $63.12 \pm 4.54 \mathrm{~mm}$. the t test shows non-significant difference between the two variables with t value 0.19 and $p$ value 0.84 .

The mean Incisal Display by using the clinical method was $0.68 \pm 1.53 \mathrm{~mm}$ while using photographic method was $0.72 \pm 1.55 \mathrm{~mm}$. the t test shows non-significant difference between the two variables with $t$ value 0.11 and $p$ value 0.91 . 
The mean upper lip length by using the clinical method was $18.61 \pm 2.62 \mathrm{~mm}$ while using photographic method was $18.38 \pm 2.64 \mathrm{~mm}$. the t test shows non-significant difference between the two variables with $\mathrm{t}$ value 0.44 and $p$ value 0.65 . The mean lower lip length by using the clinical method was $40.16 \pm 3.95 \mathrm{~mm}$ while using photographic method was $40.04 \pm 3.89 \mathrm{~mm}$. the $t$ test shows non-significant difference between the two variables with $t$ value 0.15 and $p$ value 0.88 . The result shows that the values measured by the photographic methods shows non-significant difference with the clinical values

Table 4: Genders correlation of vertical dimension with incisal display, upper lip length and lower lip length in frontal clinical examination

\begin{tabular}{|c|c|c|c|c|c|c|}
\hline Parameters & Gender & $\mathbf{N}$ & Mean & Std. Deviation & T value & $P$ Value \\
\hline \multirow{2}{*}{$\begin{array}{l}\text { vertical } \\
\text { dimension }\end{array}$} & Male & 75 & 64.48 & 4.67 & \multirow[t]{2}{*}{3.28} & \multirow[t]{2}{*}{$0.001 *$} \\
\hline & Female & 75 & 62.11 & 4.12 & & \\
\hline \multirow{2}{*}{$\begin{array}{l}\text { Incisal } \\
\text { display }\end{array}$} & Male & 75 & 1.01 & 1.69 & \multirow[t]{2}{*}{2.67} & \multirow[t]{2}{*}{$0.008^{*}$} \\
\hline & Female & 75 & 0.36 & 1.26 & & \\
\hline \multirow{2}{*}{$\begin{array}{l}\text { upper lip } \\
\text { length }\end{array}$} & Male & 75 & 19.17 & 3.04 & \multirow[t]{2}{*}{2.67} & \multirow[t]{2}{*}{$0.008^{*}$} \\
\hline & Female & 75 & 18.05 & 1.95 & & \\
\hline \multirow{2}{*}{$\begin{array}{l}\text { lower lip } \\
\text { length }\end{array}$} & Male & 75 & 41.11 & 3.47 & \multirow[t]{2}{*}{3.05} & \multirow[t]{2}{*}{$0.001 *$} \\
\hline & Female & 75 & 39.20 & 4.13 & & \\
\hline
\end{tabular}

\section{Vertical dimension for male > vertical dimension for female}

The mean vertical dimension for male was $64.48 \pm 4.67 \mathrm{~mm}$ while using photographic method was $62.11 \pm 4.12 \mathrm{~mm}$. the $t$ test shows significant difference between the two variables with $t$ value 3.28 and $p$ value 0.001

\section{Incisal Display for male > Incisal Display for female}

The mean Incisal Display for male was $1.01 \pm 1.69 \mathrm{~mm}$ while for female was $0.36 \pm 1.16 \mathrm{~mm}$. The t test shows significant difference between the two variables with $t$ value 2.67 and $p$ value 0.008

\section{Upper Lip Length for male > Upper Lip Length for female}

The mean Upper Lip Length for male was $19.17 \pm 3.04 \mathrm{~mm}$ while for female was $18.05 \pm 1.95 \mathrm{~mm}$. The $t$ test shows significant difference between the two variables with $t$ value 2.67 and $p$ value 0.008

\section{Lower Lip Length for male > Lower Lip Length for female}

The mean Lower Lip Length for male was $41.11 \pm 3.47 \mathrm{~mm}$ while for female was $39.20 \pm 4.13 \mathrm{~mm}$. The $\mathrm{t}$ test shows significant difference between the two variables with $t$ value 3.05 and $p$ value 0.001

Table 5: Gender correlation of vertical dimension with incisal display, upper lip length and lower lip length in profile clinical examination

\begin{tabular}{|l|l|c|c|c|c|c|}
\hline Parameters & \multicolumn{1}{|c|}{ Gender } & N & Mean & Std. Deviation & T value & P Value \\
\hline \multirow{2}{*}{ Vertical } & Male & 75 & 64.48 & 4.67 & \multirow{2}{*}{3.28} & \multirow{2}{*}{$0.001^{*}$} \\
\cline { 2 - 7 } & Female & 75 & 62.11 & 4.13 & & \\
\hline \multirow{2}{*}{ Upper lip } & Male & 75 & 19.17 & 3.04 & 2.67 & \multirow{2}{*}{$0.008^{*}$} \\
\cline { 2 - 7 } & Female & 75 & 18.05 & 1.96 & & \\
\hline \multirow{2}{*}{ Lower lip } & Male & 75 & 41.11 & 3.48 & \multirow{2}{*}{3.05} & $0.001^{*}$ \\
\cline { 2 - 7 } & Female & 75 & 39.20 & 4.13 & & \\
\hline
\end{tabular}


Gender comparison of vertical dimension with incisal display, upper lip length and lower lip length in profile clinical examination

The mean vertical dimension for male was $64.48 \pm 4.67 \mathrm{~mm}$ while for female was $62.11 \pm 4.12 \mathrm{~mm}$. the $\mathrm{t}$ test shows significant difference between the two variables with $t$ value 3.28 and $p$ value 0.001

\section{Upper Lip Length for male > Upper Lip Length for female}

The mean Upper Lip Length for male was $19.17 \pm 3.04 \mathrm{~mm}$ while for female was $18.05 \pm 1.95 \mathrm{~mm}$. The $t$ test shows significant difference between the two variables with $t$ value 2.67 and $p$ value 0.008

\section{Lower Lip Length for male > Lower Lip Length for female}

The mean Lower Lip Length for male was $41.11 \pm 3.47 \mathrm{~mm}$ while for female was $39.20 \pm 4.13 \mathrm{~mm}$. The $t$ test shows significant difference between the two variables with $t$ value 3.05 and $p$ value 0.001

The Correlation between variables in frontal view was done with the help of pearson correlation. The correlation coefficient value between incisal display and vertical dimension using clinical examination was 0.561 . The same result was interpreted using photographic examination at rest (0.555). Therefore incisal display shows moderate positive correlation with vertical dimension which was statistically significant. The photographic examination at smile shows weak correlation between incisal display and vertical dimension with correlation coefficient 0.149 .

The correlation coefficient value between incisal display and upper lip length was 0.436 . The same result was interpreted using photographic examination at rest (0.419) and smile (0.341). Therefore incisal display shows moderate positive correlation with upper lip length which was statistically significant.

The correlation coefficient value between upper lip length and vertical dimension was 0.561 . The same result was interpreted using photographic examination at rest $(0.535)$ and smile $(0.400)$. Therefore upper lip length shows moderate positive correlation with vertical dimension which was statistically significant.

Statistically significant positive moderate correlation between incisal display \& vertical dimension, incisal display \& upper lip and lower lip length was seen among the participants with high VD, average VD and low VD by using clinical examination, photographic examination at rest and smile. (Table 3)

Table 6: Correlation between variables in Frontal view at rest

\begin{tabular}{|c|c|c|c|c|}
\hline Parameters & Group & $\mathbf{N}$ & Pearson Correlation & $P$ value \\
\hline \multicolumn{5}{|l|}{ High VD } \\
\hline \multirow[t]{2}{*}{ Incisal Display } & vertical dimension & 69 & 0.580 & $0.001 *$ \\
\hline & upper lip length & 69 & 0.435 & $0.001 *$ \\
\hline upper lip length & vertical dimension & 69 & 0.560 & $0.001 *$ \\
\hline \multicolumn{5}{|l|}{ Average VD } \\
\hline \multirow[t]{2}{*}{ Incisal Display } & vertical dimension & 51 & 0.560 & $0.001 *$ \\
\hline & upper lip length & 51 & 0.425 & $0.001^{*}$ \\
\hline upper lip length & vertical dimension & 51 & 0.540 & $0.001 *$ \\
\hline \multicolumn{5}{|l|}{ Low VD } \\
\hline \multirow[t]{2}{*}{ Incisal Display } & vertical dimension & 30 & 0.520 & $0.001^{*}$ \\
\hline & upper lip length & 30 & 0.410 & $0.001 *$ \\
\hline upper lip length & vertical dimension & 30 & 0.515 & $0.001 *$ \\
\hline
\end{tabular}


Table 7: Correlation between variables in Frontal view at smile

\begin{tabular}{|c|c|c|c|c|}
\hline Parameters & Group & $\mathbf{N}$ & Pearson Correlation & $P$ value \\
\hline \multicolumn{5}{|l|}{ High VD } \\
\hline \multirow[t]{2}{*}{ Incisal Display } & vertical dimension & 69 & 0.170 & $0.001^{*}$ \\
\hline & upper lip length & 69 & 0.360 & $0.001^{*}$ \\
\hline upper lip length & vertical dimension & 69 & 0.420 & $0.001 *$ \\
\hline \multicolumn{5}{|l|}{ Average VD } \\
\hline \multirow[t]{2}{*}{ Incisal Display } & vertical dimension & 51 & 0.150 & $0.001^{*}$ \\
\hline & upper lip length & 51 & 0.340 & $0.001 *$ \\
\hline upper lip length & vertical dimension & 51 & 0.400 & 0.001 * \\
\hline \multicolumn{5}{|l|}{ Low VD } \\
\hline \multirow[t]{2}{*}{ Incisal Display } & vertical dimension & 30 & 0.140 & $0.001^{*}$ \\
\hline & upper lip length & 30 & 0.320 & 0.001 * \\
\hline upper lip length & vertical dimension & 30 & 0.380 & $0.001 *$ \\
\hline
\end{tabular}

The Correlation between variables in profile view was done with the help of pearson correlation. The correlation coefficient value between Nasolabial Angle and vertical dimension using clinical examination was 0.026 . The same result was interpreted using photographic examination at rest (0.029) and smile (0.027). Therefore Nasolabial Angle shows weak positive correlation with vertical dimension which was statistically non -significant. Therefore here we accept null hypothesis that there was no correlation between Nasolabial angle and vertical dimension.

The correlation coefficient value between Nasolabial Angle and upper lip length was 0.214 . The same result was interpreted using photographic examination at rest (0.209) and smile (0.211). Therefore Nasolabial Angle shows weak positive correlation with upper lip length which was statistically significant.

The correlation coefficient value between upper lip length and vertical dimension was 0.561 . The same result was interpreted using photographic examination at rest $(0.535)$ and smile $(0.400)$. Therefore upper lip length shows moderate positive correlation with vertical dimension which was statistically significant.

The same positive weak correlation between Nasolabial angle \& upper lip and positive moderate correlation upper lip length \& vertical dimension was seen among the participants with high VD, average VD and low VD by using clinical examination, photographic examination at rest and smile. (Table 9 and 3 )

Table 8: Correlation between variables in Profile view at rest

\begin{tabular}{|c|c|c|c|c|}
\hline Parameters & Group & $\mathbf{N}$ & Pearson Correlation & $P$ value \\
\hline \multicolumn{5}{|l|}{ High VD } \\
\hline \multirow[t]{2}{*}{ Incisal Display } & vertical dimension & 69 & 0.034 & 0.67 \\
\hline & upper lip length & 69 & 0.217 & $0.008^{*}$ \\
\hline upper lip length & vertical dimension & 69 & 0.560 & $0.001 *$ \\
\hline \multicolumn{5}{|l|}{ Average VD } \\
\hline \multirow[t]{2}{*}{ Incisal Display } & vertical dimension & 51 & 0.030 & 0.69 \\
\hline & upper lip length & 51 & 0.212 & $0.009 *$ \\
\hline upper lip length & vertical dimension & 51 & 0.540 & $0.001 *$ \\
\hline \multicolumn{5}{|l|}{ Low VD } \\
\hline \multirow[t]{2}{*}{ Incisal Display } & vertical dimension & 30 & 0.025 & 0.73 \\
\hline & upper lip length & 30 & 0.198 & $0.014^{\star}$ \\
\hline upper lip length & vertical dimension & 30 & 0.515 & 0.001 * \\
\hline
\end{tabular}


Table 9: Correlation between variables in Profile view at smile

\begin{tabular}{|c|c|c|c|c|}
\hline Parameters & Group & $\mathbf{N}$ & Pearson Correlation & $P$ value \\
\hline \multicolumn{5}{|l|}{ High VD } \\
\hline \multirow[t]{2}{*}{ Incisal Display } & vertical dimension & 69 & 0.037 & 0.63 \\
\hline & upper lip length & 69 & 0.219 & $0.009 *$ \\
\hline upper lip length & vertical dimension & 69 & 0.420 & 0.001 * \\
\hline \multicolumn{5}{|l|}{ Average VD } \\
\hline \multirow[t]{2}{*}{ Incisal Display } & vertical dimension & 51 & 0.028 & 0.75 \\
\hline & upper lip length & 51 & 0.211 & $0.011^{*}$ \\
\hline upper lip length & vertical dimension & 51 & 0.400 & 0.001 * \\
\hline \multicolumn{5}{|l|}{ Low VD } \\
\hline \multirow[t]{2}{*}{ Incisal Display } & vertical dimension & 30 & 0.019 & 0.85 \\
\hline & upper lip length & 30 & 0.207 & $0.013^{*}$ \\
\hline upper lip length & vertical dimension & 30 & 0.380 & 0.001 * \\
\hline
\end{tabular}

\section{DISCUSSION}

In order to effectively and accurately diagnose compounding dentoskeletal problems in the vertical dimension, the orthodontist must have an understanding of the morphologic characteristics commonly attributed to the different vertical dimension patient, as well as the types and degree of variation that can be expected within the short, average and long face patient. ${ }^{5-6}$ Many structural elements enter into the configuration of the face like cartilage, connective tissue, and musculature as well as bony tissue. Any developmental changes in the soft tissue overlying the skeletal parts, in itself, may influence facial appearance. ${ }^{7-11}$ It is pertinent that the orthodontist follows a thorough and proper diagnostic protocol to obtain consistent and predictable results. This study shows that standardized photographic technique has numerous advantages as the subject does not move, there are no skin pressure- related errors, also it is easier to take measurements, the time needed with the patient is also lesser, also it is easier for the clinician to explain the photographs to the patient rather than a cephalogram. Additionally, measurements can be made repeatedly as well as the data can be stored permanently, making longitudinal follow up studies possible. There are some disadvantages of the photographic technique as well distortion of the image due to the presence of some distance between the subject and the lens as it causes objects farther to the camera appear smaller than those closer to it . But this factor is only critical when we are making an attempt to equate structures located in the various planes of space. Furthermore, angular variables were used more often, which partially incapacitates the difficulty of magnification. cephalograms provide us with accurate measurements, their major disadvantage is the exposure of patients to radiation. With our results we can conclude that photographs can be used as an alternative to cephalograms. The advantages of photographs are that they are safe and free from radiation, easy, less time consuming, do they do not require any special equipment. ${ }^{12-15}$ Vertical facial form is an important element of orthodontic assessment. Large variations are found in the vertical dimension and these affect the clinician's approach to successful diagnosis, treatment planning, and mechanics (Nanda, 1988). Discrepancies between dentoalveolar morphology and the underlying vertical skeletal relationship might result in a deep or open bite (Beckmann et al ., 1998a ; Karlsen, 1994 ; Arat and Rubenduz, 2005 ). The upper incisor exposure was less in females when compared with males in all three groups and this difference was significant in vertical facial growth pattern group. This is contrary to the findings of Vig and Brundo, Peck et al. , and Balani et al, whereas the above finding is supported by a study done by Weeden et al., where the results demonstrated that males exhibited greater amount of facial movements than females thus increasing the incisal display on smiling. The incisal display significantly increased from horizontal to average to vertical facial growth pattern, with least incisal display in horizontal facial growth pattern subjects and maximum in vertical facial growth pattern subjects for both males and females. Contrary to this, Mc Namara et al. found that the vertical display on smile of the maxillary right central incisor could not be correlated with the skeletal vertical dimension, as measured from nasion to menton and from anterior nasal spine to menton. Upper lip vertical length of horizontal facial growth pattern group, when compared with average facial growth pattern group, indicated that upper lip vertical length was more in horizontal and 
vertical growth pattern group in both males and females and least in average growers. According to Peck et al. lip coverage of the maxillary incisors increases with age. Therefore, a high smile with $100 \%$ of the maxillary incisor exposure and a contiguous band of gingiva is characteristic of a younger population. While, McNamara et al. stated that there was no correlation between the less pleasing smile esthetics with less incisor display. In a recent study done by Suh et al. the amount of upper incisor display during posed smile was significantly increased in individuals with longer anterior maxillary height. For the present study, maxillary incisor exposure in smile esthetics was measured as the vertical distance from the inferior border of the upper lip to the incisal edge of the maxillary central incisors, and was found to have positive correlation with the skeletal vertical dimension.Research photographic records, video film, and live subjects were used to evaluate facial aesthetics (Melamed and Moss, 1975; Shaw et al., 1975; Tedesco et al., 1983b; Howells and Shaw, 1985; Cohn et al., 1986). In these studies it was found that photographic records provide valid, reproducible, and representative ratings of dental and facial aesthetics. ${ }^{16}$ Their findings suggested that photographic analysis could be used as an alternative when cephalograms cannot be obtained due to lack of availability of equipment, concerns with radiation exposure and in analysis of large number of samples in epidemiological studies. ${ }^{17-19}$

\section{CONCLUSION}

The results of the study highlights the importance of correlation of the vertical facial pattern that is vertical dimension, incisal display, upper lip length, lower lip length, clinical FMA and nasolabial angle. Photogrammetry was found to be a quick easy, cost effective and reliable diagnostic tool which can reduce radiation exposure and reduce the number of cephalograms during treatment. Evaluation of facial measurements in large samples can be carried out accurately using the non invasive method can be used for assessment for diagnosis and treatment planning. The vertical proportions of facial soft tissue following the underlying vertical skeletal pattern high vertical dimension is associated short upper lip more incisal display more clinical FMA and obtuse nasolabial angle. The low vertical dimension is associated with acute nasolabial angle and low clinical FMA. The study opens the scope of further research in the subject to substantiate the result of the research.

ImageJ imaging software developed in public domain is adequately reliable in photographic evaluation in orthodontics and can replace manual photographic analysis in orthodontics.

\section{REFERENCES}

1. Ackerman MB, Ackerman JL. Smile analysis and design in the digital era. J Clin Orthod 2002;36:221:36

2. Peerlings RH, Kuijpers-Jagtman AM, Hoeksma JB. A photographic scale to measure facial aesthetics. Eur J Orthod 1995;17:101:9.

3. Guyot L, Dubuc M, Richard O, Philip N, Dutour O. Comparison between direct clinical and digital photogrammetric measurements in patients with 22q11 microdeletion. Int J Oral Maxillofac Surg 2003; 32: 246-52.

4. Epker BN. Adjunctive esthetic surgery in the orthognathic surgery patient. In: McNamara JA, Carlson D S, Ferrara A, Ed. Esthetics and the treatment of facial form. Michigan: Center for Human Growth and Development, University of Ann Arbor 1992; p. 187.

5. Janzen EK. A balanced smile - A most important treatment objective. Am J Orthod 1977;72:359:72.

6. Kerr WJ, O'Donnell JM. Panel perception of facial attractiveness. Br J Orthod 1990;17:299:304

7. Tedesco LA, Albino JE, Cunat JJ, Green LJ, Lewis EA, Slakter MJ. A dental-facial attractiveness scale. Part I. Reliability and validity. Am J Orthod 1983;83:38:43.

8. Peck S, Peck L, Kataja M. Some vertical lineaments of lip position. Am J Orthod Dentofacial Orthop 1992;101:519:24.

9. Tsai HH. Cephalometric studies of children with long and shortfaces. J Clin Pediatr Dent 2000;25(1):23-8.

10. Steiner CS. Cephalometrics in clinical practice. Angle Orthod. 1959;29:8-29.

11. Legan Harry L, Burstone Charles J. Soft tissue cephalometric analysis for orthognathic surgery. J Oral Surg 1980;38:744-51.

12. Dolly P Patel, Rahul Trivedi Photography versus lateral cephalogram: Role in facial diagnosis. Indian J Dent Res. 2013;24(5):587-92.

13. Han K, Kwon HJ, Choi TH, Kim JH, Son D. Comparison of anthropometry with photogrammetry based on a standardized clinical photographic technique using a cephalostat and chair. J Cranio-Maxillofacial Surg. 2010;38(2):96-107.

14. Cummins DM, Bishara SE, Jakobsen JR. A computer assisted photogrammetric analysis of soft tissue changes after orthodontic treatment. Part II: Results. Am J Orthod Dentofacial Orthop. 1995;108(1):38-47.

15. Schabel BJ, Baccetti T, Franchi L, McNamara JA. Clinical photography vs digital video clips for the assessment of smile esthetics. Angle Orthod. 2010;80:490-496.

16. Peerlings RH, Kuijpers-Jagtman AM, Hoeksma JB. A photographic scale to measure facial aesthetics. Eur J Orthod 1995;17:101:9.

17. Fitzgerald Jay P, Nanda Ram S, Frans Currier G. An evaluation of the nasolabial angle and the relative inclinations of the nose and upper lip. Am J Orthod Dentofac Orthop 1992;102(4):328-34.

18. Franklin D, Hunter Stuart W. Changes in nasolabial angle related to maxillary incisor retraction. Am J Orthod 1982;82(5): 384-91.

19. Fitzgerald Jay P, Nanda Ram S, Frans Currier G. An evaluation of the nasolabial angle and the relative inclinations of the nose and upper lip. Am J Orthod Dentofac Orthop 1992;102(4): 328-34. 